\title{
Correction to: Towards lignin-protein crosslinking: amino acid adducts of a lignin model quinone methide
}

\author{
Brett G. Diehl • Heath D. Watts · James D. Kubicki - Matthew R. Regner • \\ John Ralph $\cdot$ Nicole R. Brown
}

Published online: 28 May 2019

(C) Springer Nature B.V. 2019

\section{Correction to: Cellulose (2014) 21:1395-1407 https://doi.org/10.1007/s10570-014-0181-y}

The manuscript initially failed to cite the work of Dr. Cong et al., which was the basis for this effort. We apologize for this error. The DOI for Dr. Cong's paper is: https://doi.org/10.1016/j.phytochem.2013.09.012.

Publisher's Note Springer Nature remains neutral with regard to jurisdictional claims in published maps and institutional affiliations.
The original article can be found online at https://doi.org/10.1007/s10570-014-0181-y.

\footnotetext{
B. G. Diehl ( $\square)$

Department of Agricultural and Biological Engineering, The Pennsylvania State University, 226 Forest Resources Building, University Park, PA 16802, USA

e-mail: bgd115@psu.edu

H. D. Watts

Department of Geosciences, The Pennsylvania State University, 305 Deike Building, University Park, PA 16802, USA

e-mail: hdw115@psu.edu

\section{J. D. Kubicki}

Department of Geosciences and the Earth and Environmental Systems Institute, The Pennsylvania State University, 335 Deike Building, University Park, PA 16802, USA

e-mail: jdk7@psu.edu
}

\author{
M. R. Regner · J. Ralph \\ Department of Biochemistry and DOE Great Lakes \\ Bioenergy Research Center, Wisconsin Energy Institute, \\ Madison, WI 53726, USA \\ e-mail: mregner@gmail.com \\ J. Ralph \\ e-mail: jralph@wisc.edu \\ N. R. Brown \\ Department of Agricultural and Biological Engineering, \\ The Pennsylvania State University, 209 Agricultural \\ Engineering Building, University Park, PA 16802, USA \\ e-mail: nrb10@psu.edu
}

